\title{
Factors influencing seed germination in Cerrado grasses
}

\author{
Rosana Marta Kolb ${ }^{\star \star}$, Natashi Aparecida Lima Pilon ${ }^{2}$ and Giselda Durigan ${ }^{3}$
}

Received: July 30, 2015

Accepted: November 18, 2015

\begin{abstract}
Few studies address the ecology of herbs of Cerrado grasslands, which are ecosystems where the long dry season, high temperatures, insolation, fire and invasive grasses greatly influencing germination and the establishment of plants. We assessed germination of 13 species of Poaceae from Cerrado grasslands under nursery conditions or in germination chambers, the latter with i) recently collected seeds and seeds after six months storage, ii) under constant and alternating temperatures, and iii) in the presence and absence of light. Germinability, mean germination time (MGT) and required light were quantified to elucidate factors involved in successful germination. Germinability was low for most grasses, probably because of low seed viability. For most species, germinability and MGT were not altered by seed storage. Germination percentages were higher at alternating temperatures and in the presence of light, factors that are more similar to natural environmental situations compared with constant temperature or the absence of light. Our findings indicate that alternating temperatures and light incidence are key factors for germination of species of Poaceae. The maintenance of these environmental factors, which are crucial for the conservation of Cerrado grasslands, depends on appropriate management interventions, such as fire management and the control of biological invasion.
\end{abstract}

Keywords: conservation, grasslands, Poaceae, savanna, seed storage, seed viability

\section{Introduction}

Management interventions for biodiversity conservation depend on the ecological knowledge of the species that form the ecosystems. Non-arboreal species, grasses in particular, have often been neglected not only in ecological studies, but also when setting conservation policies for different types of vegetation such as the grasslands. Difficulties in identification of grasses and especially the low value that has been attributed to the grasslands in the scenario of conservation policies (Parr et al. 2014; Veldman et al. 2015) are both causes and consequences of the poor knowledge on Cerrado grasses.

The Cerrado comprises a mosaic of vegetation types ranging from grasslands to woodlands (Walter et al. 2008), representing the savanna biome in Brazil. The biome as a whole has been neglected for conservation
(Overbeck et al. 2015), but the non-arboreal component is particularly threatened and unknown. The challenges for conservation of the Cerrado herbaceous plants start with the insufficient knowledge about these species and their reproductive processes, essential for propagation and management of the remaining populations. The influences of environmental factors such as fire, temperature or light on the germination processes in Cerrado plants have been the subject of few studies (Clarke \& French 2005; Fichino et al. 2012; Figueiredo et al. 2012; Lima et al. 2014; Musso et al. 2014; Stradic et al. 2015). Among these factors, alternating temperatures have been indicated as crucial to promote germination of Cerrado grasses (Carmona et al. 1997; Carmona et al. 1998). Seeds in grasslands are often subjected to environments with high amplitude of soil surface temperatures throughout the day, particularly after fire passage (Musso et al. 2014), a condition that could promote dormancy breaking. Other studies indicate

\footnotetext{
${ }^{1}$ Departamento de Ciências Biológicas, Faculdade de Ciências e Letras, Universidade Estadual Paulista, UNESP, Av. Dom Antônio, 2100, 19806-900, Assis, SP, Brazil

${ }^{2}$ Instituto de Biologia, Universidade Estadual de Campinas, UNICAMP, P.O. Box 6109, 13083-865, Campinas, SP, Brazil

${ }^{3}$ Floresta Estadual de Assis, Instituto Florestal do Estado de São Paulo, P.O. Box 104, 19802-970, Assis, SP, Brazil

"Corresponding author: rosanakolb@hotmail.com
} 
storage as a good technique to increase seed germination (Willis \& Groves 1991; Aires et al. 2014). However, a clear pattern does not emerge from these studies, because a wide variety of responses to the germination treatments has been observed.

From the huge diversity of herbaceous species in the Cerrado, a very small proportion has been studied, which is even more critical to the grasses (Zaidan \& Carreira 2008). Additionally, studies relating to germination under controlled conditions and ecological processes in the field are scarce. Therefore, the existing knowledge adds a limited contribution to management and conservation of the species that form the herbaceous layer of the Cerrado. This study aimed to identify environmental factors that control germination of native grasses of Cerrado, and thus contribute to a better understanding of the processes governing regeneration of these species in natural ecosystems. In this study, we evaluated seed germination of 13 species of Poaceae from Cerrado grasslands in nursery conditions or in germination chambers, the latter with i) recently collected seeds and after 6 months storage, ii) under constant and alternating temperatures, and iii) in the presence and absence of light.

\section{Materials and Methods}

\section{Collection of the diasporas \\ (here referred to as seeds]}

Seeds of native grasses were collected in a well conserved area of Cerrado vegetation at Santa Bárbara Ecological Station, state of São Paulo, Brazil (22 $46^{\prime} 41^{\prime \prime}$ S and $49^{\circ} 16^{\prime} 10^{\prime \prime} \mathrm{W}$ ). Local climate is Cfa, subtropical with hot summer, according to Köppen's classification, subject to occasional frosts. The mean temperature of the coldest months is $18^{\circ} \mathrm{C}$ and of the warmer months exceeds $22^{\circ} \mathrm{C}$; with annual rainfall of $1,000-1,300 \mathrm{~mm}$ (Alvares et al. 2013).

Thirteen species occurring in Cerrado grasslands were analyzed. Seven of these species occur in dry Cerrado grassland ("campo cerrado"): Andropogon leucostachyus Kunth, Aristida megapotamica 'brevipes' Henrard., Axonopus pressus (Nees ex Steud.) Parodi, Eustachys distichophylla (Lag.) Nees, Loudetiopsis chrysothrix (Nees) Conert, Gymnopogon foliosus (Wild.) Nees, Sorghastrum minarum (Nees) Hitchc.. The other six species occur in wet grassland ("campo úmido"): Andropogon virgatus Desv. ex Ham., Axonopus brasiliensis (Spreng.) Kuhlm., Axonopus siccus (Nees) Kuhlm., Panicum parvifolium Lam., Paspalum cordatum Hack. and Paspalum hyalinum Nees ex Trin. Seeds were manually collected at the end of the rainy season (in March 2014), except for $G$. foliosus, whose seeds are dispersed in the late dry season (September 2014). For each species, seeds were collected from at least 10 randomly selected individuals, in different areas of the ecological station, to better represent possible variations within the populations.

\section{Experiment in nursery conditions}

The experiment under nursery conditions was carried out at Assis State Forest, state of São Paulo, Brazil $\left(22^{\circ} 34^{\prime} \mathrm{S}-5^{\circ} 24^{\prime} \mathrm{W}\right)$. Similar to the climate where the seeds were collected, the local climate is Cfa (Alvares et al. 2013). The experiment with 12 species was installed in March 2014, a period in which the temperatures ranged from $17^{\circ} \mathrm{C}$ to $28^{\circ} \mathrm{C}$, whereas the experiment with $G$. foliosus was installed in September 2014, with temperatures ranging from $14^{\circ} \mathrm{C}$ to $28^{\circ} \mathrm{C}$ (CIIAGRO 2015). The freshly collected seeds were sown in plastic boxes of $12 \times 12 \times 8 \mathrm{~cm}$ with openings at the bottom for drainage of excess water. The experimental design was in randomized blocks with five blocks containing 13 boxes each. Each box represented a replicate containing 20 seeds per species, totaling five replicates and 100 seeds for each species. The seeds were sown in the boxes filled with Cerrado soil collected at Assis State Forest. The experiment was installed in the open and watered twice a day. Coleoptile emergence was recorded daily during 30 days.

\section{Experiments with seeds placed in germination chambers}

To evaluate the effect of storage on seed germination, both freshly collected and stored seeds were subjected to a constant temperature of $25^{\circ} \mathrm{C}$ under a photoperiod of 12 hours of white light, in germination chambers (20W fluorescent lamps, approximately $60 \mu \mathrm{mol} \cdot \mathrm{m}^{2} \cdot \mathrm{s}^{-1}$ ). Four replicates of 25 seeds were placed in germination boxes for each species. Seeds were placed on filter paper moistened with distilled water. Stored seeds were kept in paper bags for 6 months in laboratory environment, in a dry and dark place.

Temperature and light effects on germination were assessed only with stored seeds. Two temperature regimes were tested: constant temperature of $25^{\circ} \mathrm{C}$ and alternating temperature of $30-20^{\circ} \mathrm{C}$, in the presence (photoperiod of 12 hours) or absence of light. Four replicates of 25 seeds each were placed in germination boxes for each species. Seeds were placed on filter paper moistened with distilled water. In the dark condition the germination boxes were covered with aluminum foil. A seed was considered as germinated when presenting a radicle or coleoptile protrusion at least $1 \mathrm{~mm}$ long. Germination tests in the presence of light were assessed daily and completed within 30 days. Germination in the dark was quantified once, at the end of the tests. For each replicate, final germination percentage and mean germination time (MGT) were calculated following Labouriau (1983) and light requirement index (LRI) according to Milberg et al. (2000). 


\section{$\mathrm{LRI}=\mathrm{Gl} /(\mathrm{Gd}+\mathrm{Gl})$}

Where:

$\mathrm{Gl}$ is the germination percentage in light

$\mathrm{Gd}$ is the germination percentage under darkness

LRI ranges from zero (germination occurring only under dark conditions) to one (total light requirement); values near 0.5 indicate absence of photoblastism.

At the end of the experiment at $30-20^{\circ} \mathrm{C}$ (photoperiod of 12 hours) with stored seeds, 20-30 non-germinated seeds per species (except Gymnopogon foliosus), randomly selected, were cut and analyzed under a stereo microscope. All the seeds evaluated were classified as empty, misshapen (tiny internal content) or dead (internal content with brownish color and soft consistency).

\section{Statistical analysis}

Since the obtained data did not present normality (Shapiro-Wilks test, $\mathrm{p}<0.05$ ) and homogeneity of variances (Levene test, $\mathrm{p}<0.05$ ), results for each variable were compared by the non-parametric Mann-Whitney test $(\mathrm{p}<0.05)$.

\section{Results}

\section{Emergence in nursery condition}

Among the 13 species studied, Eustachys distichophylla presented the highest emergence. Besides this species, only Andropogon leucostachyus had more than $50 \%$ of the seedling emergence. The emergence was very low for Loudetiopsis chrysothrix, Sorghastrum minarum, Andropogon virgatus, Axonopus brasiliensis, Panicum parvifolium and Paspalum hyalinum. The emergence of Axonopus pressus seedlings was not observed (Tab.1).

\section{Freshly collected vs. stored seeds}

No differences between germination percentage of fresh and stored seeds were found ( $U \geq 4.00, p \geq 0.1416)$, except in the case of Aristida megapotamica 'brevipes' ( $\mathrm{U}<0.01$, $\mathrm{p}=0.0143)$ and $S$. minarum seeds $(\mathrm{U}<0.01, \mathrm{p}=0.0143)$, which had higher germinability after storage (Tab. 1 ). The MGT was not altered by seed storage $(\mathrm{U}>0.01, \mathrm{p} \geq$ 0.1213) (Tab. 2).

\section{Constant vs. alternating temperature}

When germination was compared under different temperature regimes, A. leucostachyus $(\mathrm{U}<0.01, \mathrm{p}=0.0209)$, A. virgatus $(\mathrm{U}<0.01, \mathrm{p}=0.0209)$, P. parvifolium $(\mathrm{U}=1.00$, $\mathrm{p}=0.0433)$ and Paspalum cordatum $(\mathrm{U}<0.01, \mathrm{p}=0.0209)$ showed higher percentage of germination at alternating temperature $\left(30-20^{\circ} \mathrm{C}\right)$ than at constant temperature $\left(25^{\circ} \mathrm{C}\right)$. Although germinability of $A$. megapotamica 'brevipes' $(\mathrm{U}=5.50, \mathrm{p}=0.4705)$ and of $G$. foliosus $(\mathrm{U}=4.50$, $\mathrm{p}=0.3123$ ) did not differ between temperature regimes (Tab. 1), the MGT was significantly higher for these species under alternating temperatures $(\mathrm{U}<0.01, \mathrm{p}=0.0209$ and $\mathrm{U}=1.00, \mathrm{p}=0.0433$, respectively) (Tab. 2).

Table 1. Seedling emergence in the nursery and final germination percentage obtained in germination chambers, of freshly collected seeds tested at $25^{\circ} \mathrm{C}$ and of 6 -months stored seeds tested at $25^{\circ} \mathrm{C}$ or at $30-20^{\circ} \mathrm{C}$ (photoperiod of 12 hours). Values are means \pm standard deviation ( $\mathrm{n}=4$, 25 seeds in each replicate).

\begin{tabular}{|c|c|c|c|c|}
\hline \multirow{2}{*}{ Species } & \multirow{2}{*}{$\begin{array}{c}\text { Emergence [\%], } \\
\text { nursery }\end{array}$} & \multicolumn{3}{|c|}{ Final germination $[\%]$} \\
\hline & & Freshly collected $\left(25^{\circ} \mathrm{C}\right)$ & After storage $\left(25^{\circ} \mathrm{C}\right]$ & After storage $\left(30-20^{\circ} \mathrm{C}\right]$ \\
\hline \multicolumn{5}{|l|}{ Dry grassland } \\
\hline Andropogon leucostachyus & $59.00 \pm 19.49$ & $2.00 \pm 2.74 \mathrm{a}$ & $4.00 \pm 5.66 \mathrm{aB}$ & $45.00 \pm 16.12 \mathrm{~A}$ \\
\hline Aristida megapotamica 'brevipes' & $28.00 \pm 14.40$ & $6.00 \pm 5.00 b$ & $22.00 \pm 6.93 \mathrm{aA}$ & $26.00 \pm 10.58 \mathrm{~A}$ \\
\hline Axonopus pressus & $0.00 \pm 0.00$ & $0.00 \pm 0.00 \mathrm{a}$ & $0.00 \pm 0.00 \mathrm{aA}$ & $0.00 \pm 0.00 \mathrm{~A}$ \\
\hline Eustachys distichophylla & $67.00 \pm 8.37$ & $76.00 \pm 4.18 a$ & $72.00 \pm 10.33 a \mathrm{~A}$ & $73.00 \pm 6.83 \mathrm{~A}$ \\
\hline Gymnopogon foliosus & $34.00 \pm 3.32$ & $86.00 \pm 9.52 \mathrm{a}$ & $92.00 \pm 3.27 \mathrm{aA}$ & $89.00 \pm 3.83 \mathrm{~A}$ \\
\hline Loudetiopsis chrysothrix & $4.00 \pm 4.18$ & $0.00 \pm 0.00 \mathrm{a}$ & $1.00 \pm 2.00 \mathrm{aA}$ & $2.00 \pm 2.31 \mathrm{~A}$ \\
\hline Sorghastrum minarum & $8.00 \pm 9.08$ & $0.00 \pm 0.00 \mathrm{~b}$ & $10.00 \pm 5.16 \mathrm{aA}$ & $16.00 \pm 6.53 \mathrm{~A}$ \\
\hline \multicolumn{5}{|l|}{ Wet grassland } \\
\hline Andropogon virgatus & $7.00 \pm 8.37$ & $1.00 \pm 2.24 \mathrm{a}$ & $0.00 \pm 0.00 \mathrm{aB}$ & $24.00 \pm 11.78 \mathrm{~A}$ \\
\hline Axonopus brasiliensis & $4.00 \pm 4.18$ & $0.00 \pm 0.00 \mathrm{a}$ & $0.00 \pm 0.00 \mathrm{aA}$ & $0.00 \pm 0.00 \mathrm{~A}$ \\
\hline Axonopus siccus & $16.00 \pm 6.52$ & $17.00 \pm 10.37 a$ & $11.00 \pm 8.25 \mathrm{aA}$ & $36.00 \pm 16.65 \mathrm{~A}$ \\
\hline Panicum parvifolium & $5.00 \pm 8.66$ & $0.00 \pm 0.00 \mathrm{a}$ & $2.00 \pm 4.00 \mathrm{aB}$ & $13.00 \pm 6.00 \mathrm{~A}$ \\
\hline Paspalum cordatum & $12.00 \pm 7.58$ & $11.00 \pm 4.18 \mathrm{a}$ & $8.00 \pm 0.00 \mathrm{aB}$ & $25.00 \pm 15.45 \mathrm{~A}$ \\
\hline Paspalum hyalinum & $5.00 \pm 6.12$ & $3.00 \pm 3.54 \mathrm{a}$ & $0.00 \pm 0.00 \mathrm{aA}$ & $5.00 \pm 6.00 \mathrm{~A}$ \\
\hline
\end{tabular}

Means followed by the same letter in the line indicate that there was no significant difference according to Mann-Whitney test (p>0.05). Lowercase letters compare between freshly collected and stored seeds at $25^{\circ} \mathrm{C}$ and uppercase letters compare between sored seeds at $25^{\circ} \mathrm{C}$ and $30-20^{\circ} \mathrm{C}$. 
Table 2. Mean germination time (MGT) of freshly collected seeds tested at $25^{\circ} \mathrm{C}$ and of 6 -months stored seeds tested at $25^{\circ} \mathrm{C}$ or at $30-20^{\circ} \mathrm{C}$ (photoperiod of 12 hours) and light requirement index (LRI) of 6 -months stored seeds tested at $25^{\circ} \mathrm{C}$ or at $30-20^{\circ} \mathrm{C}$. Values are means \pm standard deviation ( $\mathrm{n}=4,25$ seeds in each replicate).

\begin{tabular}{|c|c|c|c|c|c|}
\hline \multirow{2}{*}{ Species } & \multicolumn{3}{|c|}{ MGT [days] } & \multicolumn{2}{|c|}{ LRI } \\
\hline & Freshly collected $\left(25^{\circ} \mathrm{C}\right]$ & After storage $\left(25^{\circ} \mathrm{C}\right]$ & After storage $\left(30-20^{\circ} \mathrm{C}\right]$ & $25^{\circ} \mathrm{C}$ & $30-20^{\circ} \mathrm{C}$ \\
\hline \multicolumn{6}{|l|}{ Dry grassland } \\
\hline Andropogon leucostachyus & $17.00 \pm 0.00 a$ & $12.50 \pm 6.36 \mathrm{aA}$ & $10.18 \pm 0.50 \mathrm{~A}$ & $0.50 \pm 0.50 \mathrm{a}$ & $0.64 \pm 0.14 \mathrm{a}$ \\
\hline Aristida megapotamica 'brevipes' & $12.50 \pm 3.20 \mathrm{a}$ & $12.63 \pm 1.36 \mathrm{aB}$ & $20.09 \pm 2.78 \mathrm{~A}$ & $0.53 \pm 0.19 a$ & $0.54 \pm 0.13 a$ \\
\hline Axonopus pressus & - & - & - & - & - \\
\hline Eustachys distichophylla & $5.60 \pm 0.79 a$ & $5.21 \pm 0.44 \mathrm{aA}$ & $5.64 \pm 1.07 \mathrm{~A}$ & $0.97 \pm 0.05 \mathrm{a}$ & $0.88 \pm 0.11 \mathrm{a}$ \\
\hline Gymnopogon foliosus & $4.02 \pm 1.03 \mathrm{a}$ & $3.79 \pm 0.71 \mathrm{aB}$ & $4.94 \pm 0.28 \mathrm{~A}$ & $0.58 \pm 0.02 b$ & $0.71 \pm 0.06 \mathrm{a}$ \\
\hline Loudetiopsis chrysothrix & - & $* 7.00$ & $9.50 \pm 2.12$ & - & $0.50 \pm 0.58$ \\
\hline Sorghastrum minarum & - & $7.58 \pm 2.79 \mathrm{~A}$ & $8.16 \pm 0.70 \mathrm{~A}$ & $0.73 \pm 0.21 \mathrm{a}$ & $0.71 \pm 0.09 a$ \\
\hline \multicolumn{6}{|l|}{ Wet grassland } \\
\hline Andropogon virgatus & $* 20.00$ & - & $8.95 \pm 1.09$ & - & $1.00 \pm 0.00$ \\
\hline Axonopus brasiliensis & - & - & - & - & - \\
\hline Axonopus siccus & $9.20 \pm 2.81 \mathrm{a}$ & $6.61 \pm 3.19 \mathrm{aA}$ & $9.12 \pm 2.83 \mathrm{~A}$ & $1.00 \pm 0.00 \mathrm{a}$ & $0.77 \pm 0.11 \mathrm{~b}$ \\
\hline Panicum parvifolium & - & - & $20.00 \pm 6.03$ & - & $1.00 \pm 0.00$ \\
\hline Paspalum cordatum & $16.20 \pm 5.05 a$ & $14.62 \pm 4.87 \mathrm{aA}$ & $11.43 \pm 1.04 \mathrm{~A}$ & $0.88 \pm 0.25 a$ & $0.46 \pm 0.16 a$ \\
\hline Paspalum hyalinum & $15.50 \pm 3.54$ & - & $10.50 \pm 0.70$ & - & $1.00 \pm 0.00$ \\
\hline
\end{tabular}

*MGT calculated from a single replicate. Means followed by the same letter in the line indicate that there was no significant difference according to Mann-Whitney test ( $>0.05$ ). Lowercase letters compare MGT between freshly collected and stored seeds at $25^{\circ} \mathrm{C}$ and LRI at $25^{\circ} \mathrm{C}$ and alternating temperatures; uppercase letters compare MGT between stored seeds at $25^{\circ} \mathrm{C}$ and alternating temperatures.

\section{Light requirement index (LRI)}

The LRI values found for A. leucostachyus, A. megapotamica 'brevipes' and L. chrysothrix were close to 0.5 , indicating lack of photoblastism. Seeds from A. virgatus, Axonopus siccus, P. parvifolium, P. hyalinum, S. minarum, $G$. foliosus and E. distichophylla depend on light to germinate, with LRI values close to or equal to 1 . The LRI values for seeds of $A$. siccus differed between temperature regimes, with lower requirement for light to germinate with alternating temperatures. Seeds of $G$. foliosus also showed significant differences for LRI under different temperature regimes, however, with greater requirement of light to germinate at alternating temperatures (Tab. 2).

\section{Viability of non-germinated seeds}

All the non-germinated seeds evaluated of A. leucostachyus, A. megapotamica 'brevipes', A. pressus, E. distichophylla and $A$. virgatus were dead when analyzed at the end of the experiment with alternating temperatures. All the non-germinated seeds of L. chrysothrix, S. minarum and A. brasiliensis were misshapen, whereas all those from A. siccus, P. parvifolium, P. cordatum and P. hyalinum were empty.

\section{Discussion}

Considering the different environmental conditions to which the seeds of the 13 species were exposed, and the low germinability obtained for most of them, we can consider that low germination percentage is a pattern among Cerrado grasses, as has been observed in previous studies among non-arboreal species in the Cerrado (Lima et al. 2014; Stradic et al. 2015). Among the 13 species studied, only three had more than half of their seeds germinated under at least one of the environmental conditions tested. More than half of the species had less than $10 \%$ of seeds germinated in the nursery or in the laboratory under constant temperature. Alternating temperatures provided slightly better results than constant temperatures, but even so, $1 / 3$ of the species did not surpass $10 \%$ of germination, and only two species exceeded $50 \%$ of seeds germinated. Our data suggest that at least one of the factors involved in a low germination percentage is the low viability of the seeds (infertile or dead seeds). A high proportion of infertile seeds has been reported for Cerrado native grasses (Carmona et al. 1999). However, few studies have addressed the physiology of these species, and therefore the main factors behind the low fertility rates of the Cerrado grasses are still to be elucidated. 
Keeping the seeds stored for 6 months increased the germinability only for two species, having no positive or negative influence on the others. These results support other studies that found viable seeds of savanna grasses even after 1 year of storage (Willis \& Groves 1991; Aires et al. 2014). From the standpoint of collection and storage of seeds, this is a favorable result, since no reduction in germinability was observed at least after several months. Because seed dispersal occurs in the end of the rainy season for most species (Carmona et al. 1999; Munhoz \& Felfili 2005; Tannus et al. 2006), high longevity can be considered as a key trait that enables seeds of Cerrado grasses to remain alive during the dry season, to germinate only in the next favorable rainy season.

Considering the data obtained in the nursery and after seed storage, A. leucostachyus, A. megapotamica 'brevipes', S. minarum, A. virgatus, $P$. parvifolium and $P$. cordatum probably have dormant seeds, as alternating temperatures increased germinability, indicating dormancy alleviation. The physiological dormancy after seed dispersal occurs in many species of savanna grasslands, setting up a strategy to prevent the establishment in unfavorable conditions (Baskin \& Baskin 2014). Natural variations in environmental conditions, such as alternating temperatures, are considered important for breaking dormancy and to stimulate germination (Carmona et al. 1998; Velten \& Garcia 2005). In the field, the seeds of herbaceous species of savanna overcome the physiological dormancy during the dry season (Mott 1978; Baskin \& Baskin 2014), a fact likely related to the variation in the daily temperature during this season.

Although the alternating temperatures regime was a positive factor influencing the germination of most wet and dry Cerrado grasses in this study, the positive influence of this factor does not follow a standard for all ecosystems in the Cerrado biome. In rupestrian grasslands, in the state of Minas Gerais, Brazil, germination of herbaceous plants was not influenced by alternating temperatures (Stradic et al. 2015).

Alternating temperatures and light appear to be key factors for germination in most of the grasses analyzed, as observed by previous studies (Carmona et al. 1998; Zaidan \& Carreira 2008; Musso et al. 2014). The influence of these factors allows us to infer the appropriate environmental conditions for germination of these grasses in natural conditions, which are: open environments with direct sunlight and contrast between high temperatures at midday and low temperatures overnight. Changing these factors in nature can lead to a reduction in germination success for Cerrado grasses and, thus, may compromise the persistence of these species in the long term. Woody plants encroachment into Cerrado grasslands due to fire suppression, which has been shown by some studies (Durigan \& Ratter 2006; Cardoso et al. 2010; Pinheiro \& Durigan 2009; Pinheiro et al. 2010; Silva et al. 2013), probably alters important environmental conditions, by narrowing the amplitude of daily temperature and decreasing the availability of light. Another factor that may modify the conditions of light and microclimate close to the ground in the Cerrado is the invasion by exotic grasses (Hoffmann \& Haridasan 2008; Mendonça et al. 2015), which accumulate much more biomass on the soil surface than the native grasses.

Because grass germination is poorly documented for Cerrado (Zaidan \& Carreira 2008), our study contributes to the advancement of knowledge on these species and also to support their cultivation by the increasing demands of Cerrado restoration. The maintenance of the ideal environmental conditions for germination and persistence of grass species in the Cerrado depends on conservation and management strategies to ensure the preservation of grassland vegetation types with their peculiar structure and ecological processes. Among these strategies, maintaining an adequate fire regime or herbivory, besides prevention and control of invasion by exotic grasses stand out as the most promising strategies for the benefit of the Cerrado grasses.

\section{Acknowledgements}

Authors thank Guilherme M. Casagrande and Edivaldo R.M. Junior for helping with experiments in germination chambers. Giselda Durigan acknowledges the Conselho Nacional do Desenvolvimento Científico e Tecnológico $(\mathrm{CNPq})$ for the productivity grant awarded [\# 303402/2012-1].

\section{References}

Aires SS, Sato MN, Miranda HS. 2014. Seed characterization and direct sowing of native grass species as a management tool. Grass and Forage Science 69: 470-478.

Alvares CA, Stape JL, Sentelhas PC, Moraes G, Leonardo J, Sparovek G. 2013. Köppen's climate classification map for Brazil. Meteorologische Zeitschrift 22: 711-728.

Baskin CC, Baskin JM. 2014. Seeds: ecology, biogeography, and evolution of dormancy and germination. London, Academic Press.

Cardoso E, Moreno MIC, Bruna EM, Vasconcelos HL. 2010. Mudanças fitofisionômicas no cerrado: 18 anos de sucessão ecológica na estação ecológica do panga, Uberlândia-MG. Caminhos de Geografia 10: 254-268.

Carmona R, Camilo MGB, Martins CR. 1997. Estímulo à germinação em sementes de Gymnopogon doellii-uma gramínea ameaçada de extinção. Revista Brasileira de Fisiologia Vegetal 9: 125-130.

Carmona R, Martins CR, Fávero AP. 1998. Fatores que afetam a germinação de sementes de gramíneas nativas do cerrado. Revista Brasileira de Sementes 20: 16-22.

Carmona R, Martins CR, Fávero AP. 1999. Características de sementes de gramíneas nativas do cerrado. Pesquisa Agropecuária Brasileira 34: 1067-1074.

CIIAGRO - Centro Integrado de Informações Agrometeorológicas. 2015. Dados climáticos. Campinas: Instituto Agronômico de Campinas. http://www. ciiagro. sp. gov. br. 20 Sep. 2015. 


\section{Rosana Marta Kolb, Natashi Aparecida Lima Pilon and Giselda Durigan}

Clarke S, French K. 2005. Germination response to heat and smoke of 22 Poaceae species from grassy woodlands. Australian Journal of Botany 53: 445-454.

Durigan G, Ratter JA. 2006. Successional changes in cerrado and cerrado/forest ecotonal vegetation in western Sao Paulo State, Brazil, 1962-2000. Edinburgh Journal of Botany 63: 119-130.

Fichino B, Fidelis A, Schmidt I, Pivello V. 2012. Efeitos de altas temperaturas na germinação de sementes de capim-dourado (Syngonanthus nitens (Bong.) Ruhland, Eriocaulaceae): implicações para o manejo. Acta Botanica Brasilica 26: 508-511.

Figueiredo MA, Baêta HE, Kozovits AR. 2012. Germination of native grasses with potential application in the recovery of degraded areas in Quadrilátero Ferrífero, Brazil. Biota Neotropica 12: 118-123.

Hoffmann WA, Haridasan M. 2008. The invasive grass, Melinis minutiflora, inhibits tree regeneration in a Neotropical savanna. Austral Ecology 33: 29-36.

Labouriau LG. 1983. A germinação das sementes. Washington, Secretaria Geral da Organização dos Estados Americanos - OEA.

Lima YBC, Durigan G, Souza FM. 2014. Germinação de 15 espécies vegetais do cerrado sob diferentes condições de luz. Bioscience Journal 30: 864-1872.

Mendonça AH, Russo C, Melo AC, Durigan G. 2015. Edge effects in savanna fragments: a case study in the cerrado. Plant Ecology \& Diversity 1-11.

Milberg P, Andersson L, Thompson K. 2000. Large-seeded species are less dependent on light for germination than small-seeded ones. Seed Science Research 10: 99-104.

Mott JJ. 1978. Dormancy and germination in five native grass species from savannah woodland communities of the Northern Territory. Australian Journal of Botany 26: 621-631.

Munhoz CBR, Felfili JM. 2005. Fenologia do estrato herbáceo-subarbustivo de uma comunidade de campo sujo na Fazenda Água Limpa no Distrito Federal, Brasil. Acta Botanica Brasilica 19: 979-988.

Musso C, Miranda HS, Aires SS, Bastos AC, Soares AM, Loureiro S. 2014. Simulated post-fire temperature affects germination of native and invasive grasses in cerrado (Brazilian savanna). Plant Ecology \& Diversity 8: 1-9.
Overbeck GE, Vélez-Martin E, Scarano FR, et al. 2015. Conservation in Brazil needs to include non-forest ecosystems. Diversity and Distributions 21: 1455-1460.

Parr CL, Lehmann CE, Bond WJ, Hoffmann WA, Andersen AN. 2014 Tropical grassy biomes: misunderstood, neglected, and under threat. Trends in Ecology \& Evolution 29: 205-213.

Pinheiro EDS, Durigan G. 2009. Dinâmica espaço-temporal (1962-2006) das fitofisionomias em unidade de conservação do Cerrado no sudeste do Brasil. Revista Brasileira de Botânica 32: 441-454.

Pinheiro MH, Azevedo TSD, Monteiro R. 2010. Spatial-temporal distribution of fire-protected savanna physiognomies in Southeastern Brazil. Anais da Academia Brasileira de Ciências 82: 379-395.

Silva LC, Hoffmann WA, Rossatto DR, Haridasan M, Franco AC, Horwath WR. 2013. Can savannas become forests? A coupled analysis of nutrient stocks and fire thresholds in central Brazil. Plant and Soil 373: 829-842.

Stradic S, Silveirav FA, Buisson E, Cazelles K, Carvalho V, Fernandes, GW. 2015. Diversity of germination strategies and seed dormancy in herbaceous species of campo rupestre grasslands. Austral Ecology 40: 537-546.

Tannus JLS, Assis MA, Morellato LPC. 2006. Fenologia reprodutiva em campo sujo e campo úmido numa área de cerrado no sudeste do Brasil, Itirapina - SP. Biota Neotropica 6: bn02806032006.

Veldman JW, Buisson E, Durigan G, et al. 2015. Toward an old-growth concept for grasslands, savannas, and woodlands. Frontiers in Ecology and the Environment 13: 154-162.

Velten SB, Garcia QS. 2005. Efeitos da luz e da temperatura na germinação de sementes de Eremanthus (Asteraceae), ocorrentes na Serra do Cipó, MG, Brasil. Acta Botanica Brasilica 19: 753-761.

Walter BMT, Carvalho, AM, Ribeiro JF. 2008. O conceito de savana e de seu componente Cerrado. In: Sano SM, Almeida SP, Ribeiro JF (eds.) Cerrado: ecologia e flora. Brasília, Embrapa. p. 21-45.

Willis AJ, Groves RH. 1991. Temperature and light effects on the germination of seven native forbs. Australian Journal of Botany 39: 219-228.

Zaidan LB, Carreira RC. 2008. Seed germination in Cerrado species. Brazilian Journal of Plant Physiology 20: 167-181. 